\title{
Evaluasi Penggunaan Obat Berdasarkan Indikator Peresepan dan Pelayanan Pasien di Rumah Sakit Tora Belo
}

Khusnul Diana, Aviva Kumala, Nina Nurlin, Muhamad Rinaldhi Tandah*

Program Studi Farmasi, Fakultas Matematika dan Ilmu Pengetahuan Alam, Universitas Tadulako, Palu, Indonesia

*Corresponding author: prof.aldhi@gmail.com

Submitted: 10 November 2020

Accepted: 31 December 2020

Published: 09 April 2021

\begin{abstract}
Background: Pharmaceutical care is an integrated activity to identify, prevent, and solve problems related to medicine and health in order to optimize rational drug use. Objective: This study was aimed to evaluate the use of drugs based on indicators of prescribing practices by the health providers and patient care at Tora Belo Hospital, Sigi Regency. Methods: This study was conducted by analyzing retrospective and prospective data. Prescribing indicators were used to count average number of drug, generic drug, antibiotic, injection and essential drug/hospital formulary's drug written on prescription. The sample of prescription was taken from hospitalized patient's prescriptions as many as 391 sheets by purposive sampling technique. Meanwhile, patient service indicators were taken from 269 outpatients by accidental sampling technique. Results: Average number of drugs per prescription sheet was 3.1 (standard: 1.8 - 2.2); the proportion of drug use was generic drugs 74.89\% (standard: $81-94 \%$ ), antibiotics $45.52 \%$ (standard: $\leq 30 \%$ ), injection $6.90 \%$ (standard: $0.2-48 \%$ ), respectively; Drug conformity with the hospital formulary was $99.17 \%$ (standard: $86-88 \%$ ). Additionally, from the patient service indicators, the average consultation time was 4.32 minutes (standard: 2.3 - 3.5 minutes); dispensing time of between pre-manufactured and extemporaneous compounded drugs was 11.42 and 22.54 minutes, respectively; percentage of drugs given 94.54\% (standard: 100\%); ratio of drug label completeness 100\%; and percentage of patient knowledge about the use of the correct dose 48.12\% (standard: 100\%), respectively. Conclusion: The use of drugs did not fit into WHO standard in terms of prescription indicator. Nevertheless, it has met indicator standard for services.
\end{abstract}

Keywords: drug utilization, hospital formulary, pharmacy service, prescribing

\begin{abstract}
Abstrak
Pendahuluan: Praktik kefarmasian merupakan kegiatan terpadu untuk mengidentifikasi, mencegah serta menyelesaikan masalah yang berkaitan dengan obat dan kesehatan untuk meningkatkan penggunaan obat yang rasional. Tujuan: Untuk mengevaluasi penggunaan obat berdasarkan indikator peresepan yang ditulis oleh dokter dan pelayanan pasien di RSUD Tora Belo, Kabupaten Sigi. Metode: Penelitian dilakukan secara retrospektif dan prospektif. Indikator peresepan digunakan untuk menghitung rata-rata jumlah obat, obat generik, antibiotik, suntik dan obat esensial/obat formularium rumah sakit yang tertera pada setiap lembar resep. Sampel resep diambil dari resep pasien umum rawat sebanyak 391 lembar dengan teknik purposive sampling, sedangkan indikator pelayanan pasien diambil dari pasien rawat jalan sebanyak 269 pasien dengan teknik accidental sampling. Hasil: Rata-rata penggunaan obat tiap lembar resep adalah 3,1 (standar: 1,8 - 2,2); persentase obat generik adalah 74,89\% (standar: 81 - $94 \%$ ); persentase obat antibiotik adalah 45,52\% (standar: $\leq 30 \%$ ); persentase obat injeksi adalah 6,90\% (standar: 0,2 - 48\%); dan persentase kesesuaian obat dengan formularium rumah sakit adalah $99,17 \%$ (standar: $86-88 \%$ ). Sedangkan dari indikator pelayanan pasien diperoleh rata-rata waktu konsultasi 4,32 menit (standar: 2,3 - 3,5 menit); rata-rata dispensing time obat non racikan 11, 42 dan racikan 22,54 menit; persentase obat yang diberikan $94,54 \%$ (standar: $100 \%$ ); persentase kelengkapan label obat sebesar $100 \%$; dan persentase pengetahuan pasien tentang penggunaan dosis yang tepat $48,12 \%$ (standar: $100 \%$ ).
\end{abstract}


Kesimpulan: Penggunaan obat belum memenuhi standar WHO jika dilihat dari indikator peresepan, namun masih memenuhi standar WHO jika dilihat dari indicator pelayanan.

Kata kunci: formularium, pelayanan, penggunaan obat, peresepan

\section{PENDAHULUAN}

Salah satu faktor yang menentukan keberhasilan dalam pelayanan kefamasian adalah penggunaan obat yang rasional. WHO mendefinisikan penggunaan obat yang rasional, yaitu pasien menerima obat sesuai dengan kebutuhan kliniknya, pada dosis yang tepat secara individual, waktu pemakaian terukur, dan terjangkau harganya oleh pasien yang bersangkutan, atau masyarakat sekelilingnya. Pemakaian obat yang tidak rasional merupakan masalah serius dalam pelayanan kesehatan karena kemungkinan dapat terjadi dampak negatif (Satibi dkk., 2016).

Dalam menuliskan resep yang tepat dan rasional, seorang dokter harus memiliki pengetahuan dasar yang cukup terkait dengan ilmu-ilmu farmakologi, meliputi farmakodinamik, farmakokinetik, dan sifat fisiko-kimia obat yang diberikan. Oleh karena itu, dokter mempunyai peranan penting dalam proses pelayanan kesehatan, khususnya dalam melaksanakan pengobatan yang diberikan kepada pasien dengan pemberian obat melalui resep.

Empat puluh tiga (43) studi evaluasi indikator peresepan yang melibatkan 11 negara di Afrika, yaitu sebanyak 572 fasilitas kesehatan primer dengan 141.223 pasien dan menggunakan indikator peresepan obat yang dibuat oleh WHO, diketahui bahwa penulisan resep di fasilitas swasta tidak lebih baik dibandingkan fasilitas milik pemerintah (Ofori-Asenso dkk., 2016).

Sebuah studi lain yang mengumpulkan data sebanyak 757 resep di 26 Puskesmas dan 900 resep dari 30 klinik/praktek dokter pribadi yang tersebar di 4 propinsi (Jawa Barat, Banten, Daerah Istimewa Yogyakarta, dan Jawa Tengah) berhasil mengukur bahwa penggunaan obat generik dan obat dari daftar formularium nasional lebih banyak dilakukan di Puskesmas dibanding klinik/praktek pribadi (Yuniar dkk., 2017).

Kedua riset tersebut menggambarkan bahwa penulisan resep masih menggunakan obat-obat yang masih di bawah standar WHO.
Rumah Sakit Tora Belo merupakan rumah sakit pemerintah di Kabupaten Sigi, Sulawesi Tengah. Didirikan pada tahun 2015 dan ikut merasakan dampak gempa bumi di tahun 2018 menyebabkan kerusakan beberapa fasilitas yang telah ada. Selain itu, keberadaan tenaga kefarmasian yang terbatas juga ikut menjadi masalah dalam pengelolaan perbekalan farmasi di rumah sakit. Seperti yang dikatakan Puspasari dkk. (2017) dalam penelitiannya, bahwa ketersediaan sumber daya manusia dalam pengelolaan obat sangat penting dalam sebuah organisasi. Untuk mendukung kelancaran operasi organisasi, rumah sakit harus memenuhi kebutuhan tenaga kesehatan baik dalam aspek kuantitas, kompetensi, dan persamaan hak dan kewajiban.

Tujuan dari penelitian ini adalah mengevaluasi penggunaan obat berdasarkan indikator peresepan dan indikator pelayanan pasien mengacu pada standar WHO.

\section{METODE}

Penelitian ini menggunakan 2 indikator, yaitu indikator peresepan obat dan pelayanan pasien. Cara purposive sampling dilakukan untuk mengukur peresepan obat secara retrospektif, yaitu memenuhi kriteria resep obat pada pasien rawat jalan dari semua poliklinik di Rumah Sakit Tora belo dari bulan Januari hingga Desember 2018. Resep obat yang dievaluasi tersimpan di Instalasi Farmasi Rumah Sakit Tora Belo. Untuk mengukur pelayanan pasien dilakukan secara prospektif dengan dengan menemui dan mengikuti pasien yang ditemui yang bersedia diwawancara di apotek rawat jalan (accidental sampling).

\section{HASIL DAN PEMBAHASAN}

Hasil penelitian penggunaan obat untuk indikator peresepan dan pelayanan pasien seperti terlihat pada Tabel 1. 
Tabel 1. Data penggunaan obat di RSUD Tora Belo

\begin{tabular}{lcc}
\hline \multicolumn{1}{c}{ Penggunaan Obat } & Standar & Hasil \\
\hline Indikator Peresepan & & \\
1. Rata-rata jumlah obat dalam resep & $1,8-2,2$ & 3,1 \\
2. Persentase obat generik dalam resep & $81-94 \%$ & $74,89 \%$ \\
3. Persentase antibiotik dalam resep & $\leq 30 \%$ & $45,52 \%$ \\
4. Persentase injeksi dalam resep & $0,2-48 \%$ & $6,90 \%$ \\
5. Persentase kesesuaian antara obat dalam resep denga formularium & $86-88 \%$ & $99,17 \%$ \\
rumah sakit & & \\
\hline Indikator Pelayanan pasien & & \\
1. Rata-rata waktu konsultasi (menit) & $2,3-3,5$ & \\
2. Rata-rata dispensing time (menit) & & 22,32 \\
a. Resep Racikan & - & 11,42 \\
b. Resep Non Racikan & - & $94,54 \%$ \\
3. Persentase obat yang diberikan & $100 \%$ & $100 \%$ \\
4. Persentase kelengkapan label obat & $100 \%$ & \\
\hline
\end{tabular}

\section{Indikator peresepan}

Resep obat yang diperoleh dari bulan Januari hingga Desember 2018 sebanyak 391 lembar resep.

\section{Rata-rata jumlah obat dalam resep}

Indikator rata-rata jumlah item obat per lembar resep bertujuan untuk mengetahui terjadinya polifarmasi atau tidak. Polifarmasi merupakan penggunaan beberapa macam obat pada seorang pasien yang dapat menempatkan pasien pada kondisi berbahaya, yaitu reaksi efek samping dan hasil klinis yang buruk, termasuk kekurangan nutrisi, jatuh, menjadi lemah, gangguan kognitif, lebih sering dirawat di rumah sakit, dan kematian dini. Mengurangi polifarmasi adalah salah satu prioritas WHO yang bertujuan untuk mengurangi separuh beban global dari bahaya terkait pengobatan (Page dkk., 2019).

Hasil penelitian di RSUD Tora Belo menunjukan bahwa jumlah obat tiap lembar resep diperoleh ratarata 3,1 obat/lembar resep dimana hasil tersebut tidak sesuai dengan standar WHO yang mana rata-rata jumlah obat tiap lembar resep yaitu 1,8 2,2 obat/lembar resep. Dari penelitian diketahui bahwa jumlah obat paling banyak dalam tiap resep adalah 7 item obat. Peresepan obat berlebih dapat menimbulkan dampak negatif yaitu dapat meningkatkan risiko kejadian efek samping obat, meningkatkan kejadian interaksi obat, dan meningkatkan beban biaya obat yang diterima oleh pasien. Berdasarkan penelitian oleh Renfan dkk. (2013) di RSUD Karel Sadsuitubun Kabupaten Maluku Tenggara dengan hasil $3,23 \mathrm{obat} / \mathrm{lembar}$ resep yang juga tidak sesuai dengan standar WHO.

Banyaknya obat yang dituliskan dalam resep lebih kepada mengurangi gejala yang dialami pasien. Jika lebih berfokus pada penyakit utama, maka sedikit yang perlu dituliskan dalam resep, selama simptom penyakit dapat ditoleransi pasien. Tidak semua keluhan pasien harus mendapatkan obat. Selain itu, terdapat pilihan pengobatan non farmakologis yang dapat diobservasi lebih dalam.

\section{Persentase obat generik dalam resep}

Indikator persentase peresepan obat dengan nama generik bertujuan untuk mengetahui kecenderungan peresepan obat dengan nama generik. Berdasarkan hasil penelitian menunjukan bahwa penggunaan obat generik hanya $74,89 \%$ dari total resep yang ditemukan. Hal tersebut disebabkan dokter masih banyak yang meresepkan obat dengan nama dagang/paten seperti, Cendo xitrol, Cendo LFX, Cendo lyters, Cendo poligran, Ketomed shampoo, Kloderma krim, Lantus pen, Umaron injeksi, Caviplex, Call 95, Novorapid pen, Buscopan, Symbicort, Gabesco, Vitalex, Channa, Ultrogestan, Harnal, Analtram, Micardis, Tekesol krim, Vip albumin, Avesco, Flamicort, Apyalis drop, Fuson krim, Tremenza, Dexacort krim, Ardium, New diatabs, Levemir pen, Lubire, L-Bio, Cortidex, Vitonal, Calporis, Depakote, beberapa obat paten tersebut sebagian besar sudah tercantum dalam Formularium Rumah Sakit. Penggunaan obat paten karena tidak tersedia dalam bentuk obat generiknya. Penelitian Pebriana dkk. (2018) di RSUD Ir. Soekarno Sukoharjo adalah $52,83 \%$ juga tidak sesuai dengan target $\mathrm{WHO}$, yaitu $81-94 \%$.

\section{Persentase antibiotik dalam resep}

Indikator persentase peresepan antibiotik bertujuan untuk mengukur penggunaan antibiotik pada setiap pasien. Penggunaan antibiotik diberikan untuk pasien yang terindikasi adanya infeksi oleh bakteri sehingga penggunaannya harus tepat.

Hasil penelitian menunjukan bahwa persentase peresepan antibiotik sebesar 45,52\%, dimana standar WHO yaitu $\leq 30 \%$. Beberapa antibiotik tersebut adalah 
Amoxicillin, Cendo LFX, Cefadroxyl, Levofloxacin, Gentamisin, Ciprofloxacin, Cendo poligran, Doksisiklin, Azytromicin, Cefixime, Cotrimoxazole, Clindamicin, Eritromisin. Terdapat Metronidazol yang mana sering dianggap sebagai antibiotik tetapi lebih sering digunakan sebagai antiprotozoal dalam hal ini tidak dihitung sebagai antibiotik. Sementara salep mata dan tetes mata antibiotik, krim kulit antibiotik dihitung sebagai antibiotik (WHO, 1993). Hasil penelitian serupa oleh Ihsan dkk. (2017) diperoleh hasil 36,85\%. Penelitian lain oleh Yuniar dkk. (2017) diperoleh penggunaan antibiotik $42,8 \%$. Kedua penelitian tersebut juga tidak sesuai standar WHO yaitu $\leq 30 \%$.

Penggunaan antibiotik tidak diatur dalam Standar Pelayanan Minimal (SPM) rumah sakit. Idealnya antibiotik dapat diresepkan jika gejala penyakit bertahan, kondisi imunitas pasien tidak memungkinkan untuk recovery dari infeksi yang ada, dan pembuktian infeksi oleh mikroba dari pengujian laboratorium. Dalam pelaksanaannya, antibiotik diresepkan pada kondisi demam dan keluhan pasien yang mengarah pada gejala infeksi berlangsung lebih dari 3 hari, tanpa pengujian spesimen atas kontaminasi mikroba patogen.

\section{Persentase injeksi dalam resep}

Persentase penggunaan sediaan injeksi untuk mengetahui kecenderungan penggunaan injeksi pada pasien rawat jalan di RSUD Tora Belo Kabupaten Sigi. Berdasarkan hasil penelitian diperoleh persentase penggunaan injeksi tiap resep yaitu $6,90 \%$. Penggunaan injeksi cenderung diberikan pada pasien yang berasal dari Poliklinik Ortopedi dan Traumatologi. Injeksi yang diresepkan yaitu seperti Eperison $\mathrm{HCl}$ yang digunakan sebagai antispasmodik Umaron injeksi (Sodium Hyaluronate) digunakan sebagai agen reumatoid, Hypobhac injeksi (Netilmicin sulphate) digunakan untuk pengobatan pada infeksi serius, Lidokain ampul digunakan sebagai agen anastetik lokal. Berdasarkan hasil penelitian oleh Yuniar dkk. (2017) penggunaan injeksi dari seluruh resep sebanyak $0,7 \%$. Penggunaan sediaan ini sesuai dengan indikasi kondisi pasien dan diinjeksikan kepada pasien di rumah sakit segera setelah pasien menebus resep obat.

\section{Persentase kesesuaian antara obat dalam resep dengan formularium rumah sakit}

Berdasarkan pada Buku Standar Pelayanan Minimal Rumah Sakit yang dikeluarkan oleh Departemen Kesehatan RI pada tahun 2008, standar pelayanan minimal untuk farmasi terkait dengan kesesuaian peresepan dengan Formularium Rumah Sakit adalah $100 \%$, apabila persentase kurang dari
$100 \%$ maka dapat dikatakan dokter tidak patuh dalam menuliskan resep.

Hasil penelitian menjunjukan persentase kesesuaian antara obat dalam resep dengan formuarium rumah sakit di RSUD Tora Belo Kabupaten Sigi yaitu sebesar $99,17 \%$ hasil tersebut sesuai dengan standar WHO yaitu 86\% - 88\%. Di RSUD Tora Belo Kabupaten Sigi terdapat beberapa obat yang tidak tercantum atau tidak sesuai digunakan berdasarkan Formularium Rumah Sakit yaitu diantaranya Miconazole krim, Hepa-Q, Calporis, L-Bio, Cuticell, Lubire, Vitonal, H-Booster. Hasil penelitian oleh Pebriana dkk. (2018) adalah 92,47\% dimana tidak sesuai dengan standar WHO yaitu batas ketidaksesuaiannya berkisar $86 \%$ hingga $88 \%$. Ketidaksesuaian tersebut dapat terjadi karena beberapa faktor, yaitu diantaranya dokter penulis resep merupakan dokter baru di rumah sakit, dan obat tersebut diresepkan karena pasien membutuhkan, meskipun tidak tercantum di dalam formularium rumah sakit.

\section{Indikator pelayanan pasien}

Untuk mengukur pelayanan pasien, sampel pasien yang bersedia diwawancarai sebanyak 269 pasien.

\section{Rata-rata waktu konsultasi}

Rata-rata waktu konsultasi adalah waktu yang diperlukan oleh dokter untuk menyampaikan informasi kepada pasien. Pengamatan waktu konsultasi pasien dengan dokter dilakukan selama 6 hari kerja yaitu senin-sabtu di semua poliklinik (poli internal/penyakit dalam, poli mata, poli gigi, poli bedah, poli saraf, poli ortopedi, poli anak, poli kulit dan kelamin dan poli obstetri dan ginekologi) yang terdapat pada RSUD Tora Belo Kabupaten Sigi. Data yang diambil sebagai sampel penelitian sebanyak 269 pasien rawat jalan.

Dari hasil penelitian yang telah dilakukan diperoleh rata-rata waktu yang dibutuhkan pasien untuk konsultasi dengan dokter yaitu 4 menit 32 detik dengan waktu konsultasi terendah yaitu 1 menit 19 detik dan waktu konsultasi tertinggi 12 menit 51 detik, melebihi waktu konsultasi yang telah direkomendasikan. Rekomendasi rata-rata waktu konsultasi untuk penelitian ini adalah 2,3 - 3,5 menit (WHO, 1993).

Yang mempengaruhi lamanya waktu konsultasi pasien dengan dokter di RSUD Tora Belo Kabupaten Sigi adalah banyaknya jumlah pasien yang datang berobat atau melakukan konsultasi setiap harinya. Selain itu adanya kandidat dokter pada beberapa poli yang juga menjadi faktor penyebab lamanya waktu konsultasi. Setiap konsultasi, dokter memberikan 
pertanyaan kepada dokter koas yang sedang mendapatkan pelatihan sehingga memperlama waktu konsultasi. Waktu konsultasi yang dilakukan oleh dokter bervariasi bergantung pada banyaknya informasi mengenai penyakit yang disampaikan serta pemahaman pasien tentang pengobatan.

Hasil penelitian yang telah dilakukan sebelumnya oleh Yuliastuti dkk. (2013) diperoleh rata-rata waktu konsultasi pasien dengan dokter di Rumah Sakit Umum Daerah Sleman Yogyakarta melebihi dari waktu rata-rata yang telah ditetapkan WHO.

\section{Rata-rata dispensing time}

Rata-rata waktu penyiapan dan penyerahan obat adalah durasi yang diperlukan petugas farmasi mulai dari menerima resep sampai dengan menyerahkan obat kepada pasien. Indikator ini bertujuan untuk mengukur waktu rata-rata yang dibutuhkan oleh seorang petugas farmasi dalam menyiapkan obat-obat untuk pasien yang dalam hal ini berhubungan kinerja pelayanan yang diberikan. Data yang diambil sebagai sampel penelitian sebanyak 269 pasien rawat jalan yang membawa resep ke instalasi farmasi rawat jalan, dimana 51 sampel untuk pasien yang membawa resep racikan dan 218 sampel untuk pasien yang membawa resep non racikan. Data pemeriksaan untuk parameter indikator dispensing time diperoleh sejak pasien menyerahkan resep obat pada petugas farmasi, penyiapan obat sampai penyerahan obat kepada pasien.

Dari hasil penelitian yang telah dilakukan, ratarata waktu dispensing obat non racikan di RSUD Tora Belo Kabupaten Sigi pada Instalasi Farmasi Rawat Jalan adalah 11,43 menit per lembar resep, sedangkan rata-rata waktu dispensing obat racikan di RSUD Tora Belo Kabupaten Sigi pada Instalasi Farmasi Rawat Jalan adalah 24,54 menit. Dari hasil penelitian, diperoleh waktu pemberian obat yang sangat bervariasi mulai dari waktu penyiapan obat terendah yaitu 2 menit 38 detik untuk obat non racikan dan 12 menit 29 detik obat racikan sedangkan waktu penyiapan obat tertinggi yaitu 32 menit 4 detik obat non racikan dan 38 menit 26 detik obat racikan.

Hasil tersebut menunjukkan bahwa target waktu penyiapan obat yang ditentukan oleh manajemen apotek rawat jalan RSUD Tora Belo hampir dapat dipenuhi yaitu waktu dispensing obat racikan $\leq 25$ menit dan waktu dispensing obat non racikan $\leq 10$ menit. Waktu penyiapan obat bervariasi dapat dipengaruhi oleh perbedaan tenaga petugas farmasi yang melayani resep dimana resep yang masuk pada instalasi farmasi rawat jalan RSUD Tora Belo dilayani oleh satu orang untuk tiap resepnya dimulai dari penerimaan resep, penyiapan obat, sampai pemberian obat kepada pasien serta pemberian informasi obat sehingga ada petugas yang cepat dalam melayani adapula yang lambat, hal lain yang mempengaruhi lamanya waktu penyiapan obat yaitu jumlah pasien yang harus dilayani tidak diimbangi dengan jumlah tenaga kefarmasian yang memadai sehingga kekurangan tenaga kefarmasian di rumah sakit ini juga berpengaruh pada kecepatan pelayanan resep. Tingkat kesulitan suatu resep juga dapat mempengaruhi waktu penyiapan obat, kesulitan yang dimaksud yaitu kesulitan pada resep racikan karena tidak hanya menyiapkan obat, juga melakukan perhitungan dosis obat, menimbang bahan yang akan digunakan, mengambil berapa banyak obat yang diperlukan sesuai dengan dosis yang diperlukan serta juga harus memperhatikan dalam mencampur jenis bahan obat lalu meracik obat dan mengubah sediaan.

Namun, jika melihat standar dispensing time yang telah ditetapkan (Permenkes RI, 2016), waktu penyiapan obat terpenuhi yaitu waktu dispensing obat racikan $\leq 60$ menit dan waktu dispensing obat non racikan $\leq 30$ menit. Penelitian yang dilakukan Karuniawati dkk. (2016) rata-rata waktu yang dibutuhkan untuk menyelesaikan obat racikan dan obat non racikan di RSUD Kota Salatiga yaitu pelayanan resep baik obat jadi maupun obat racikan di instalasi farmasi rawat jalan sudah memenuhi standar Permenkes RI (2016) yaitu lama waktu tunggu obat racikan $\leq 60$ menit dan obat jadi $\leq 30$ menit.

\section{Persentase obat yang diberikan}

Indikator obat yang diberikan memiliki tujuan untuk mengukur sejauh mana fasilitas kesehatan mampu menyediakan obat yang diresepkan. Penyerahan obat secara aktual menunjukkan semua obat yang diresepkan dapat diberikan kepada pasien. Data yang diambil sebagai sampel penelitian sebanyak 269 pasien rawat jalan yang membawa resep ke instalasi farmasi rawat jalan, data pemeriksaan untuk parameter indikator persentase obat yang diberikan diperoleh dengan melihat obat yang diterima oleh pasien dari petugas farmasi kemudian disesuaikan dengan jumlah obat yang diresepkan.

Persentase obat yang diberikan kepada pasien pada di Instalasi Farmasi Rawat Jalan RSUD Tora Belo sebesar 94,54\%. Berdasarkan WHO (1993), untuk menghitung proporsi obat yang diberikan dengan menghitung jumlah obat yang diberikan dibagi dengan total item obat yang dituliskan dalam resep. Dalam hal ini, dari 752 item obat yang diresepkan, hanya tersedia 711 item obat yang dapat diberikan kepada pasien. Hal 
tersebut menunjukkan bahwa sebagian besar pengadaan obat di rumah sakit telah sesuai dengan pola peresepan obat dan pola penyakit yang ada di Kabupaten Sigi, tercukupinya persediaan obat di bagian gudang farmasi rumah sakit, serta sebagian besar pengadaan obat yang dilakukan di RSUD Tora Belo telah sesuai dengan formulariumnya. Obat yang tidak terlayani yaitu sebanyak 41 item obat $(5,46 \%)$, yang dapat disebabkan karena kekosongan obat dan obat pengganti habis pada saat yang bersamaan. Namun, kekosongan obat di Instalasi Farmasi Rawat Jalan RSUD Tora Belo ini tidak mempengaruhi pengobatan di rumah karena pada rumah sakit ini juga terdapat apotek lain yang menjadi apotek pembantu untuk rumah sakit tersebut. Pasien akan diberikan salinan resep dari instalasi farmasi rawat.

Penelitian di kota Depok dilakukan Makhdalena dkk. (2018), diperoleh persentase obat yang diserahkan kepada pasien di Puskesmas yang belum terakreditasi sebesar 80,7\% dan Puskesmas terakreditasi 78,7\%. Rendahnya obat yang dapat diserahkan kepada pasien menunjukkan ketersediaan obat di Puskesmas belum mencukupi kebutuhan obat.

\section{Persentase kelengkapan label obat}

Pengukuran ketepatan pelabelan obat dilakukan melalui pengamatan langsung terhadap label atau etiket yang diserahkan oleh petugas farmasi kepada pasien yang diberikan bersamaan dengan obat yang diresepkan. Pengamatan dilakukan setiap hari dimana sampel adalah semua pasien rawat jalan yang telah melakukan konsultasi dengan dokter serta diberi resep untuk menebus obat di Instalasi Farmasi Rawat Jalan RSUD Tora Belo Kabupaten Sigi. Menurut WHO (1993) komponen informasi minimal yang harus tertera di label obat adalah nama pasien, nama obat, tanggal obat diserahkan serta cara/aturan penggunaan obat. Sedangkan di instalasi farmasi rawat jalan RSUD Tora Belo komponen yang terdapat dalam label obat adalah tanggal lahir, tanggal resep, nomor rekam medik, nama pasien, nama obat, sediaan obat dan cara/aturan penggunaan obat serta keterangan.

Berdasarkan hasil pengamatan diperoleh tingkat ketepatan pemberian label sampel sebesar 100\%, sehingga semua sampel yang diamati oleh peneliti telah mengandung komponen yang diisyaratkan oleh instalasi farmasi rawat jalan RSUD Tora Belo Kabupaten Sigi. Label tersebut telah memiliki format penulisan standar dan diisi oleh petugas farmasi Instalasi Farmasi Rawat Jalan dengan tulisan tangan yang jelas dan mudah dibaca oleh pasien. Informasi yang memadai merupakan hak dari seorang pasiendimana ketepatan pelabelan obat sangat erat kaitannya dengan jaminan keamanan pasien dalam penggunaan obat. Adapun dampak dari obat dengan pelabelan yang tidak memadai memungkinkan pasien salah minum obat dan memungkinkan terjadinya efek obat yang tidak diharapkan. Penelitian yang dilakukan Destiani dkk. (2016), persentase obat yang dilabeli dengan benar di salah satu apotek di Bandung telah sesuai dengan standar dimana hasil penelitiannya sebesar $100 \%$. Penelitian yang dilakukan Sudarmono dkk. (2011) di Rumah Sakit Panti Nugroho Sleman persentase ketepatan pemberian label obat di Rumah Sakit Panti Nugroho Sleman sebagian besar sampel yang diamati telah mengandung komponen minimal yang telah disyaratkan oleh IFRS Panti Nugroho Sleman.

\section{Pengetahuan pasien tentang penggunaan dosis yang tepat}

Data untuk indikator pengetahuan pasien tentang penggunaan dosis didapat setelah mengajukan beberapa pertanyaan kepada pasien setelah pasien tersebut menebus obat di Instalasi Farmasi Rawat Jalan RSUD Tora Belo. Persentase pengetahuan dosis dihitung berdasarkan pembagian sejumlah pasien yang menunjukkan pengetahuan dosis cukup dengan jumlah total pasien yang diberikan pertanyaan dikalikan 100 . Data yang diambil sebagai sampel penelitian sebanyak 269 pasien rawat jalan yang membawa resep ke Instalasi Farmasi Rawat Jalan serta obat yang diresepkan dokter diberikan kepada pasien.

Berdasarkan hasil penelitian yang telah dilakukan didapatkan hasil bahwa persentase pasien yang paham akan penggunaan dosis yang tepat sebesar $47,58 \%$. Sebagian besar pasien tidak dapat mengulang dengan tepat informasi yang diberikan oleh petugas farmasi rawat jalan. Jika yang ditanyakan adalah nama obat, sebanyak $79,18 \%$ pasien menjawab dengan benar. Dari pertanyaan aturan pakai obat, sebesar 96,28\% memberikan jawaban yang tepat. Hal ini menunjukkan bahwa sebagian besar pasien paham aturan pakai obat, tetapi tidak tahu berapa dosis dari tiap obat yang akan diminum serta sebagian pasien tidak tahu baca obat yang diberikan sehingga tidak tahu nama dari obat tersebut. Pasien yang datang berobat di RSUD Tora Belo merupakan pasien-pasien BPJS yang merupakan pasien yang diharuskan rutin mengkonsumsi obat. Penyebab lain yang menyebabkan persentase pasien yang tidak paham akan cara penggunaan dosis di Rumah Sakit Tora Belo adalah pasien lanjut.

Penelitian sebelumnya yang dilakukan (Sudarmono dkk., 2011) diketahui bahwa sebagian 
besar pasien Rumah Sakit Panti Nugroho Sleman dapat mengulang dengan tepat dan informasi yang diberikan oleh petugas IFRS.

\section{KESIMPULAN}

Penggunaan obat di Rumah Sakit Tora Belo belum memenuhi persyaratan jika dilihat dari indikator peresepan standar WHO. Jika dilihat dari indikator pelayanan pasien, rata-rata waktu penyiapan obat (baik obat racikan maupun non racikan), persentase obat yang diberikan, dan kelengkapan label obat, masih dalam rentang standar WHO.

\section{UCAPAN TERIMA KASIH}

Terima kasih kepada Panitia Pelaksana kegiatan seminar nasional dan temu ilmiah di Fakultas Farmasi Universitas Airlangga, yang telah memberikan kesempatan untuk mempresentasikan hasil penelitian ini secara virtual tanggal 26 September 2020. Terima kasih pula kepada Kepala Instalasi Farmasi RSUD Tora Belo Kabupaten Sigi yang telah memberikan izin untuk melaksanakan penelitian.

\section{DAFTAR PUSTAKA}

Destiani, D. P., Naja, S., Nurhadiyah, A., Halimah, E. \& Febrina, E. (2016). Pola Peresepan Rawat Jalan: Studi Observasional Menggunakan Kriteria Prescribing Indicator WHO di Salah Satu Fasilitas Kesehatan Bandung. Jurnal Farmasi Klinik Indonesia; 5; 225-231.

Ihsan, S., Sabarudin, Leorita, M., Syukriadi, A. S. Z. \& Ibrahim, M. H. (2017). Evaluasi Rasionalitas Penggunaan Obat Ditinjau dari Indikator Peresepan Menurut World Health Organization (WHO) di Seluruh Puskesmas Kota Kendari Tahun 2016. Jurnal Medula; 5; 402-409.

Karuniawati, H., Hapsari, I. G., Arum, M., Aurora, A. T. \& Wahyono, N. A. (2016). Evaluasi Pelaksanan Standar Pelayanan Minimal (SPM) Farmasi Kategori Lama Waktu Tunggu Pelayanan Resep Pasien Rawat Jalan di Rsud Kota Salatiga. Kartika Jurnal Ilmiah Farmasi; 4; 20-25.

Makhdalena, Jufri, M. \& Andrajati, R. (2018). Analisis Pelayanan Kefarmasian Berdasarkan Indikator Pelayanan Pasien WHO pada Puskesmas Kecamatan yang Belum dan Sudah Terakreditasi di Kota Depok. Jurnal Kefarmasian Indonesia; $8 ; 137-143$.

Ofori-Asenso, R., Brhlikova, P. \& Pollock, A. M. (2016). Prescribing Indicators at Primary Health Care Centers within the Who African Region: a
Systematic Analysis (1995-2015). BMC Public Health; 16; 1-14.

Page, A. T., Falster, M. O., Litchfield, M., Pearson, S.A. \& Etherton-Beer, C. (2019). Polypharmacy among older Australians, 2006-2017: a Population-Based Study. The Medical Journal of Australia; 211; 71-75.

Pebriana, P., Puspitaningtyas, P. H. \& Sasongko, H. (2018). Penilaian Pola Penggunaan Obat berdasarkan Indikator Peresepan WHO di RSUD Ir. Soekarno Sukoharjo. Borneo Journal of Pharmascientech; 2; 23-30.

Permenkes RI. (2016). Standar Pelayanan Kefarmasian di Rumah Sakit. Jakarta: Kemeterian Kesehatan RI.

Puspasari, H., Danu, S. S. \& Sulistyani, E. (2017). ABC Analysis Towards Drug Needs Planning in Pharmacy Installation of RSUD Kota Yogyakarta in 2010. Jurnal Farmasi Dan Ilmu Kefarmasian Indonesia; 4; 69-73.

Renfan, W. W., Fudholi, A. \& Widodo, G. P. (2013). Evaluasi Pengelolaan Obat dan Strategi Perbaikan dengan Metode Hanlon di Instalasi Farmasi Rumah Sakit Umum Daerah Karel Sadsuitubun Kabupaten Maluku Tenggara Tahun 2012. Prosiding Seminar Nasional Perkembangan Terkini Sains Farmasi dan Klinik III 2013 Fakultas Farmasi Universitas Andalas; 247-257.

Satibi, Dewi, D. A. P. S., Akhmad, A. D., Kaswindiarti, N. \& Puspandari, D. A. (2016). Persepsi Apoteker dan Pasien terhadap Penerapan Sistem Pembayaran JKN pada Apotek. Journal of Management and Pharmacy Practice; 6; 219-228.

Sudarmono, C. A., Purnomo, A. \& Sudjaswadi, R. (2011). Analisis Penggunaan Obat pada Pasien Rawat Jalan di Rumah Sakit Panti Nugroho Sleman Periode Oktober 2008. Jurnal Manajemen Dan Pelayanan Farmasi; 1; 24-29.

WHO. (1993). How to Investigate Drug Use in Health Facilities. Geneva: WHO.

Yuliastuti, F., Purnomo, A. \& Sudjaswadi, R. (2013). Analisis Penggunaan Obat pada Pasien Rawat Jalan di Rumah Sakit Umum Daerah Sleman Yogyakarta Periode April 2009. Media Farmasi; 10; 104-1113.

Yuniar, Y., Susyanty, A. L. \& Sari, I. D. (2017). Assessment of Prescribing Indicators in Public and Private Primary Healthcare Facilities in Java Island, Indonesia Study setting Province (Bekasi City and Bogor district), Banten Province (Tangerang Selatan City and Serang District, Central Java Pro. Jurnal Kefarmasian Indonesia; 7; 55-66. 